\title{
New Product Warranty: Empirical Evidence from Polish and Slovenian Furniture Industry
}

\section{Jamstvo novih proizvoda: empirijsko iskustvo poljske i slovenske industrije namještaja}

\author{
Original scientific paper • Izvorni znanstveni rad \\ Received-prispjelo: 19. 2. 2016. \\ Accepted-prihvaćeno: 15. 11. 2016. \\ UDK: $630 * 79$ \\ doi:10.5552/drind.2017.1610
}

\begin{abstract}
The aim of the study was to recognize the attitudes towards new product warranty issues in marketing practice of furniture manufacturers. The results of a survey conducted among 75 Polish and Slovenian furniture companies are presented, focusing on whether enterprises use the information concerning the length of warranty period offered for manufactured products in their marketing materials and in which cases they build their competitive strategy and strengthen their corporate identity based on warranty issues. Data collected through direct interviews and surveys was subjected to a comprehensive statistical analysis using statistical grouping method, cluster analysis and correspondence analysis. The results showed that most often the information on the length of warranty period is used commercially by manufacturers of furniture for children and kitchen furniture. The coexistence of variables connected with the offered warranty period for furniture products, the use of information concerning warranty in advertising materials, implementation of a long-term design management strategy, the development of a positive image of the company in the market based on the comprehensive visual identity project and the limited number of years when the company has been operating in the market was showed.
\end{abstract}

Key words: new products, product warranty, competitive advantage, empirical study, statistical analysis

SAŽETAK • Cilj istraživanja bio je upoznati mišljenja proizvođača namještaja o jamstvima proizvoda koji se pojavljuju u marketinškoj praksi. Prikazani su rezultati ankete provedene među 75 poljskih i slovenskih proizvođača namještaja. Naglasak ankete bio je na pitanju koriste li se poduzeća informacijama o duljini razdoblja jamstava što ih u svojim marketinškim materijalima nude za proizvode i u kojim slučajevima na jamstvima za proizvode grade svoju konkurentsku strategiju i jačaju svoj korporativni identitet. Podaci prikupljeni izravnim intervjuima $i$ anketama podvrgnuti su sveobuhvatnoj statističkoj analizi uz pomoć statističke metode grupiranja, klasterske analize i analize korespondencije. Istraživanja su pokazala da se informacijama o trajanju jamstvenog roka najčešće komercijalno koriste proizvođači namještaja za djecu i proizvođači kuhinjskog namještaja. Iz analize rezultata potvrđena je i koegzistencija varijabli povezanih s ponudom jamstvenog roka za namještaj, s uporabom informacija vezanih za jamstvo u reklamnim materijalima, s provođenjem dugoročne strategije upravljanja dizajnom,

\footnotetext{
${ }^{1}$ Authors are associate professors at Poznan University of Life Sciences, Faculty of Wood Technology, Department of Furniture Design, Poznan, Poland. ${ }^{2}$ Author is associate professor at Associated Member of University of Primorska, Faculty of design, An Independent Higher Education Institute, Interior design, Trzin, Slovenia.

Autori su izvanredni profesori Sveučilišta prirodnih znanosti u Poznanu, Fakultet drvne tehnologije, Odjel za dizajn namještaja, Poznan, Poljska. ${ }^{2}$ Autorica je izvanredna profesorica Sveučilišta Primorska, Fakultet dizajna, Neovisni institut visokog obrazovanja, Dizajn interijera, Trzin, Slovenija.
} 
s razvojem pozitivne predodžbe o tvrtki na tržištu, stvorene na temelju sveobuhvatnog projekta izrade vizualnog identiteta, kao i s ograničenim brojem godina tijekom kojih tvrtka posluje na tržištu.

Ključne riječi: novi proizvodi, jamstvo za proizvod, konkurentska prednost, istraživanje, statistička analiza

\section{INTRODUCTION 1. UVOD}

In contemporary highly competitive economies of well developed countries both quality and reliability of the product, as well as the length and terms of the warranty period, are significant factors of competitive advantage. Furniture companies are facing strong competition in the contemporary global market. They must continually strive to improve or at least maintain their market share. Consumers are nowadays very demanding and they require as much as possible information about the product to be sure about its quality (Oblak and Glavonjić, 2014). Kotler (2000) indicated that together with other aspects such as e.g. external form of the product, its functionality, price, brand, material, etc., they comprise various levels of the product, affecting evaluation of a given product by potential consumers. Frequently, next to the core of the product, i.e. the set of basic benefits received by the consumer when purchasing a given goods, the decision of acquisition is determined by categories comprising the actual product, such as e.g. the price, quality, packaging, brand, and such additional benefits (added value) as e.g. extended warranty (Kotler, 2000; Kotler et al., 2002). For this reason, when designing and launching new products, enterprises should consider these issues and adequately implement them in marketing activities (Menezes and Currim, 1992). Such an approach should be adopted particularly in the case of durable goods such as e.g. furniture (Udell and Anderson, 1968; Wiener, 1985) or automotive industry (Majeske et al., 1997; Zhoua et al., 2012). Increased interest in issues of reliability, quality and warranty can be observed in the furniture industry (Ratnasingam et al., 1997; Gremyr et al, 2003; Smardzewski, 2005, 2009; Kłos and Fabisiak, 2010). Reliability is an essential feature determining the commercial success of a product and it is a significant element in the competitive strategy of the enterprise (Sander and Brombacher, 2000; Murthy and Djamaludin, 2002; Murthy, 2006; Murthy, 2007; Kłos and Fabisiak, 2013a, 2013b; Ojurović et al, 2013). It is of importance both for furniture producers (Vickery et al., 1997) and consumers (Udell and Anderson, 1968; Sinclair and Hansen, 1993; Pakarinen and Asikainen, 2001; Ratnasingam, 2003; Chien et al., 2005; Knauf, 2015). Numerous authors point out that quality is particularly demanded on wood products market (Schubert, 1979; Kozak and Maness, 2003). Taking the above into consideration, the aim of the study was to gather information concerning the attitudes towards quality, reliability and warranty issues in Polish and Slovenian companies manufacturing furniture, as well as the methods of applying knowledge on these aspects in the operation of furniture enterprises.

\section{MATERIALS AND METHODS} 2. MATERIJALI I METODE

It was decided to collect data concerning the above subject using questionnaire studies and direct interviews. The assumed population size was 100 furniture factories located in Poland and Slovenia. The analyzed sample of enterprises was selected on the basis of a quota selection method taking into account the size of the company and geographical structure. The aim of additional in-depth interviews was explanatory research to provide better understanding of the subject and remarks from the manufacturers' point of view as well as reasons staying behind their decisions concerning the studied issues. They were performed among 30 companies manufacturing case type furniture and much interested in the topic of product reliability. Polish companies constituted $60 \%$ of this sample and Slovenian enterprises $40 \%$. Collected data were coded and then subjected to a statistical analysis with the use of STATISTICA 10.0 software. Data analysis was performed applying the statistical grouping method, taking into account the division of the units based on the criteria of country of origin and realization of a longterm strategy of brand creation. Stratified sampling, with respect to this criterion, was used to explore the hypothesis that those companies exhibit a greater awareness of the need to ensure quality and reliability of produced pieces of furniture and build a positive image in the market based on that. In turn, sampling was conducted taking into account the location of the company to discover whether there are differences between attitudes of furniture manufacturers in the analyzed countries. Moreover, cluster analysis was conducted. The method according to Ward (1963) was applied as the agglomeration algorithm, which makes it possible to estimate the distances between clusters using the analysis of variance approach, as it aims to minimize the sum square of deviations within clusters. Moreover, correspondence analysis was used to investigate the coexistence of variables concerning such characteristics as the age of the company, using the information on warranty in marketing materials, providing an extended warranty period for produced furniture and realization of a long-term strategy for design development and brand creation in the market.

Taking into consideration the percentage of returned questionnaires, their completeness and the number of direct interviews performed, it was decided to conduct further statistical analyses based on data gathered from 75 units. The distribution of the sample according to the level of employment was as follows: micro companies $4 \%$, small companies $35 \%$, medium companies $43 \%$ and big ones $18 \%$. The distribution of the sample regarding geographic location of compa- 
nies, according to the preliminary assumptions, represents the structure of furniture industry in the investigated countries based on national statistics.

\section{RESULTS AND DISCUSSION}

\section{REZULTATI I RASPRAVA}

Within the conducted study, it was first decided to determine whether, in the face of increasing competition, enterprises use information concerning the length of the warranty period in their marketing materials in order to focus the attention of potential customers on the additional benefits offered in connection with a given product. The conducted analysis showed that, both among the Polish and Slovenian companies participating in the study, the percentage of enterprises providing such information in their advertising materials was around $50 \%$. A detailed analysis conducted using statistical grouping methods, including data concerning the size of the enterprise, showed that none of the surveyed companies with the staff of max. 9 employees provided information on the length of the warranty period in their advertising materials (Figure 1). In contrast, the percentage of companies using such information to fight their market competition increased with an increase in the size of enterprise. In the case of companies with more than 250 employees it was as much as $75 \%$.

It was also decided to specify whether the level of usage of information concerning the length of the warranty period in the marketing materials of furniture manufacturing companies varies depending on the type and purpose of produced furniture. It was shown that the analyzed problem was of greatest importance for the manufacturers of furniture for children and teenagers as well as kitchen furniture (Figure 2). All of the analyzed Polish and Slovenian companies producing such furniture informed their prospective customers on the warranty period offered for their furniture.

Information collected during in-depth direct interviews indicated that this was connected, among other things, with the very long period of use of kitchen furniture and with the particular focus of customers on safety issues in the case of furniture designed for children and teenagers. This is confirmed by the results of research conducted e.g. by Udell and Anderson (1968), which indicated that the effectiveness of the use of warranty in marketing is best when a given product is purchased rarely or it seems complicated to the consumers. Information on the length of the warranty period is included much less frequently in advertising materials of companies producing e.g. upholstered furniture.

Incorporation of information concerning warranty in marketing materials was also related to the degree of involvement of the company in actions associated with building their own brand i.e. activities connected with the brand development and its strengthening as well as having a visual identity project and the consistent development of a positive corporate image based on the long-term strategy for the development of design operations. Differences were found in the activity of furniture enterprises in this respect (Figure 3).

Conducted analyses showed that $82 \%$ of the analyzed companies had their own brand, while only $69 \%$ entities undertook actions connected with its development and strengthening. Investments in the purchase of

Do you use the information

on the length of the warranty period in your marketing materials?

Koristite li informaciju o duljini razdoblja jamstva u vašim marketinškim materijalima?

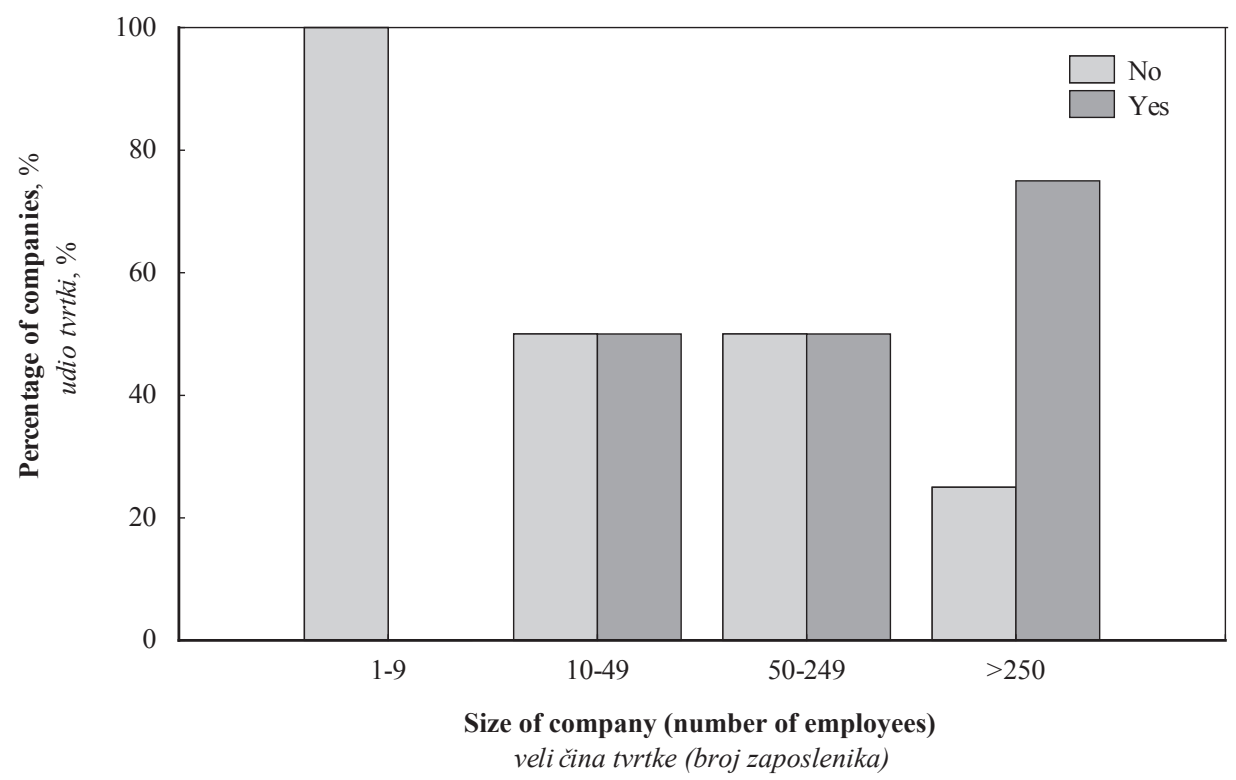

Figure 1 The distribution of analyzed enterprises in terms of their use of information on the length of the warranty period in their advertising materials depending on the size of enterprise

Slika 1. Raspodjela analiziranih poduzeća sa stajališta korištenja informacijama o duljini razdoblja jamstva za proizvode u reklamnim materijalima i ovisno o broju zaposlenih 


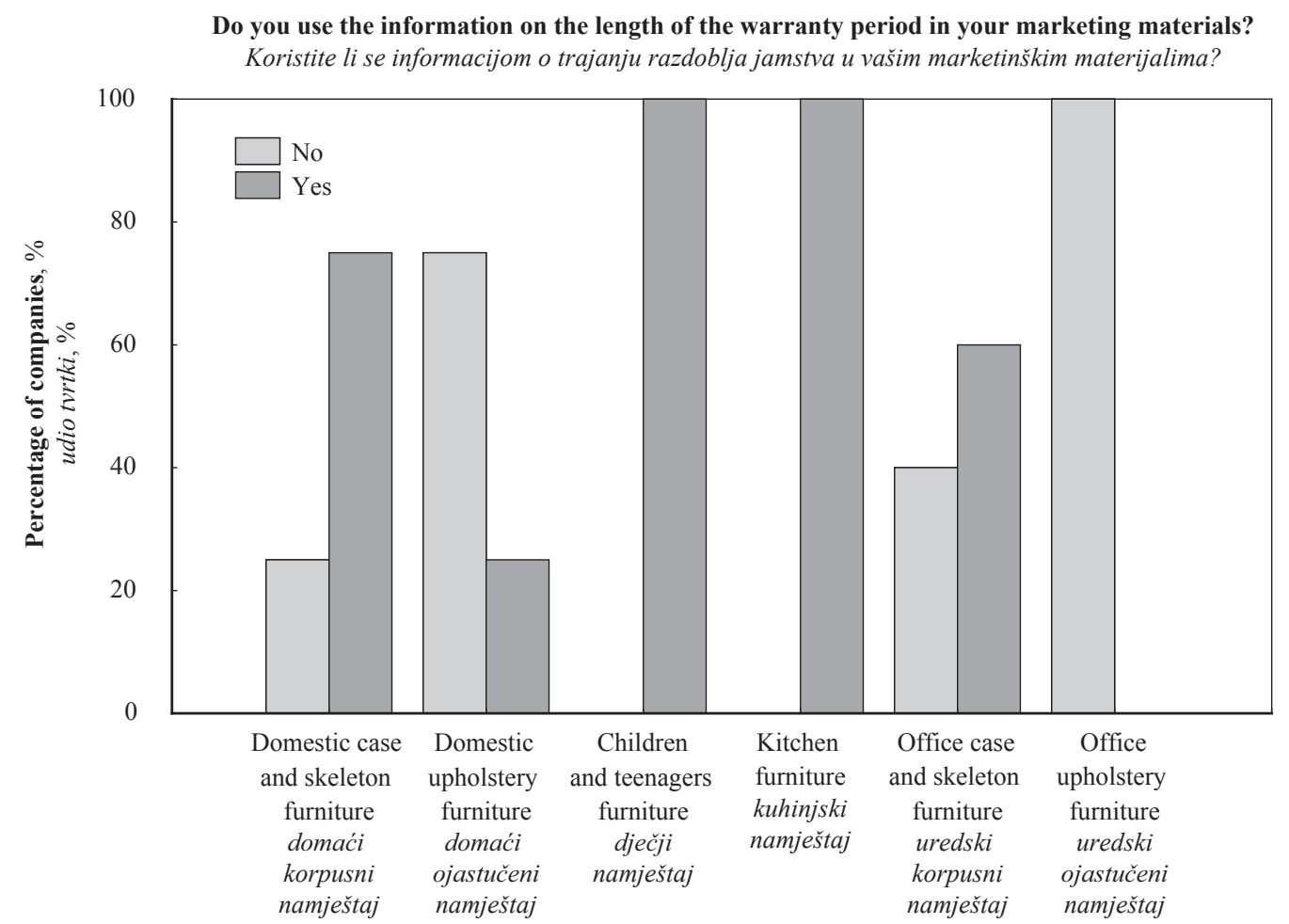

Figure 2 The distribution of analyzed enterprises in terms of use of information on the length of the warranty period in their advertising materials depending on the type of produced furniture

Slika 2. Raspodjela analiziranih poduzeća sa stajališta korištenja informacijama o duljini razdoblja jamstva za proizvode u reklamnim materijalima i ovisno o vrsti namještaja koji proizvode

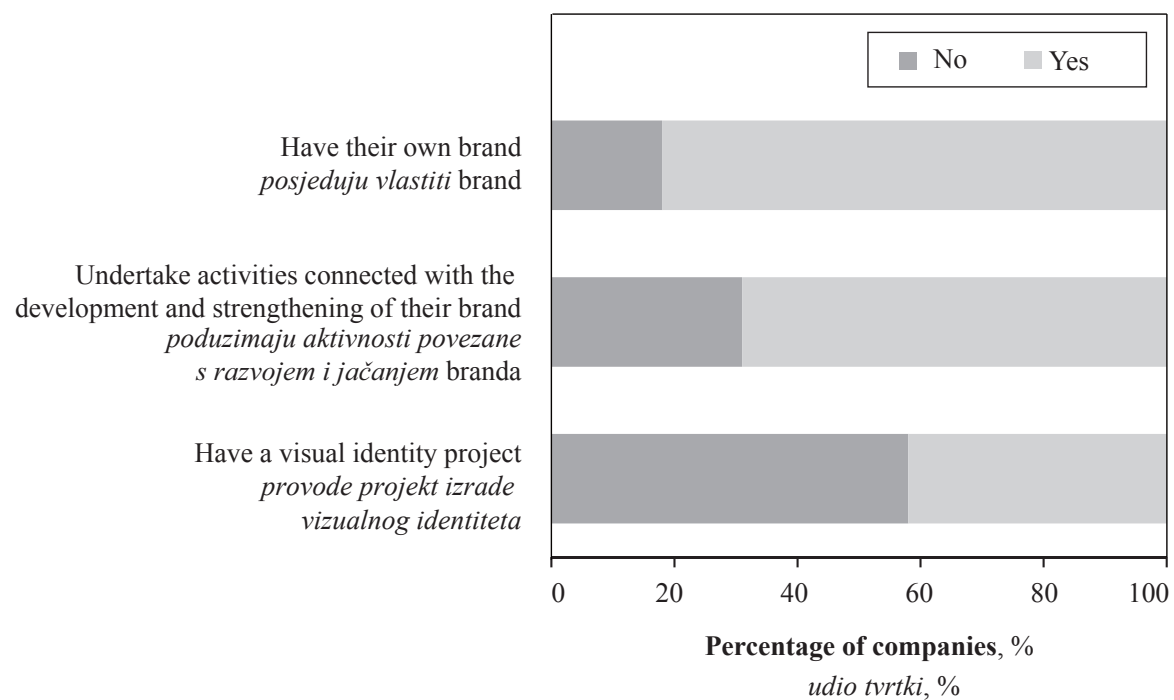

Figure 3 The distribution of analyzed furniture enterprises in terms of having their own brand, undertaking activities connected with the development and strengthening of their brand, having a visual identity project

Slika 3. Raspodjela analiziranih poduzeća za proizvodnju namještaja s obzirom na posjedovanje vlastitog branda, s obzirom na poduzimanje aktivnosti povezanih s razvojem i jačanjem tog branda te s provođenjem projekta izrade vizualnog identiteta

the visual identity project were only made by $42 \%$ of the analyzed entities. Companies belonging to this group showed the greatest awareness of the benefits associated with the conscious creation of a brand and a positive corporate image in the market and also with the development of design operations. It was shown that this group of enterprises attained much better business results and received awards for high design value of their product range more frequently than the others. Observations presented above are confirmed by the chi-square test of independence for variables concern- ing the existence of the visual identity project in a given enterprise (variable $X$ ) and received awards for design (variable $Y$ ). The distribution of analyzed variables is presented in Figure 4 and in Table 1.

A verification procedure was conducted for the zero hypothesis specified as follows:

$\mathrm{H}_{0}$ : variables $X$ and $Y$ are independent in relation to the alternative hypothesis,

$\mathrm{H}_{1}$ : variables $X$ and $Y$ are not independent.

Results of the $\chi^{2}$ test presented in Table $1\left(\chi^{2}\right.$ $=24.5117$ at $p=0.00000)$ mean that it is admissible to 
..... Fabisiak, Kłos, Hrovatin: New Product Warranty: Empirical Evidence from Polish and...

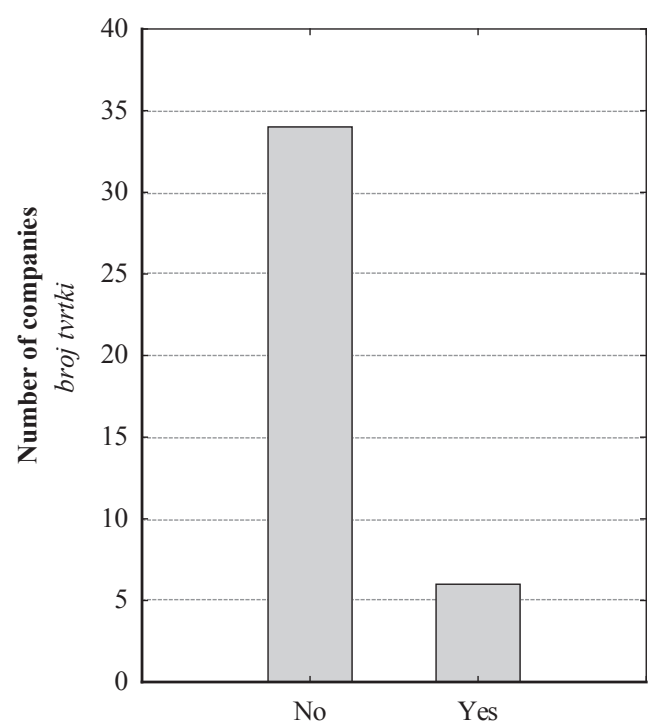

Visual identity project - No

projekt vizualnog indentiteta - ne

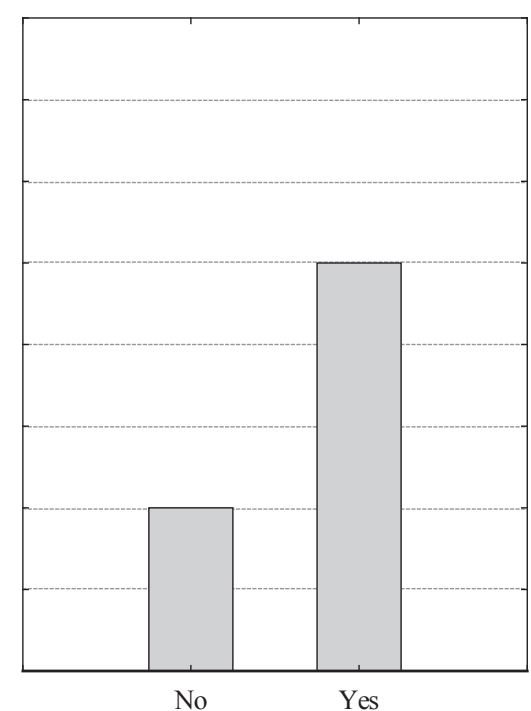

Visual identity project - Yes

projekt vizualnog indentiteta - da

Award for high design quality

nagrada za visoku kvalitetu dizajna

Figure 4 The distribution of analyzed furniture enterprises depending on their having a visual identity project and received awards for high design quality

Slika 4. Raspodjela analiziranih poduzeća za proizvodnju namještaja s obzirom na provedbu projekta izrade vizualnog identiteta i nagrada dobivenih za visoku kvalitetu dizajna namještaja

Table 1 Results of the chi-square independence test for variables: visual identity project and award for good design Tablica 1. Rezultati $\chi^{2}$-testa za varijable projekt vizualnog identiteta i nagrada za dizajn proizvoda

\begin{tabular}{|l|c|c|c|}
\hline & $\chi^{2}$ & $\begin{array}{c}\text { Number of degrees of freedom } \\
\text { Stupanj slobode }\end{array}$ & $\begin{array}{c}\text { Level of significance } \\
\text { Razina signifikantnosti }\end{array}$ \\
\hline$\chi^{2}$ Pearson & 24.5117 & $D f=1$ & $p=0.00000$ \\
\hline Contingency coefficient / koeficijent kontingencije & 0.4963 & & \\
\hline$\tau$-b Kendall's coefficient / Kendallov koeficijent & 0.5717 & & \\
\hline
\end{tabular}

reject the zero hypothesis on the independence of analyzed variables and to assume an alternative hypothesis on the existence of a relationship between investment by the enterprise in the visual identity project and receiving honors or awards for design. The value of the contingency coefficient $\mathrm{C}$ amounting to 0.4963 in the case of quality traits indicates a relatively strong correlation between variables. The existence of a strong positive relationship is also evidenced by the value of Kendall's $\tau$-b coefficient ( $b=0.5717)$.

A detailed analysis of data coming from enterprises in both investigated countries showed that these companies used more frequently information on the length of the offered warranty period in their advertising materials. It should also be stressed here that enterprises without an active policy to establish their brand in the market did not present such information (Figure 5). The greatest percentage of companies, which built their competitive advantage using also information on the length of the warranty period offered for manufactured products, was found in the group of firms that invested in the visual identity project (Figure 6). These were enterprises that exhibited the greatest awareness of the benefits provided by the implementation of a comprehensive, clearly defined strategy of development and establishment of their own brand in the mar- ket, focusing on the quality and high design value of manufactured products. The above results were confirmed during the in-depth interviews with representatives of the studied units.

Data collected during comprehensive direct interviews showed that the more frequent presentation of information on the length of the warranty period for manufactured products in marketing materials was connected with the implementation of the strategy to create a positive image of the enterprise in the market based on customer trust and dedication to ensure high quality and reliability of products.

The chi-square test of independence was conducted for the analyzed variables. Verification was performed on the zero hypothesis specified as follows: $\mathrm{H}_{0}$ : variable $X$ (information on the length of the warranty period for manufactured products incorporated in advertising materials of the company) and variable $Y$ (creation of the brand based on the company visual identity project) are independent, in relation to the alternative hypothesis $\mathrm{H}_{1}$ : variables $X$ and $Y$ are not independent. Results of the test indicate that this dependence is significant at $p=0.07898\left(\chi^{2}=3.085714\right)$. Thus, we may reject the zero hypothesis on the independence of analyzed variables and accept the alternative hypothesis on the existence of a relationship be- 
Do you use the information

on the length of the warranty period in your marketing materials? Koristite li se informacijom o duljini razdoblja jamstva u vašim marketinškim materijalima?

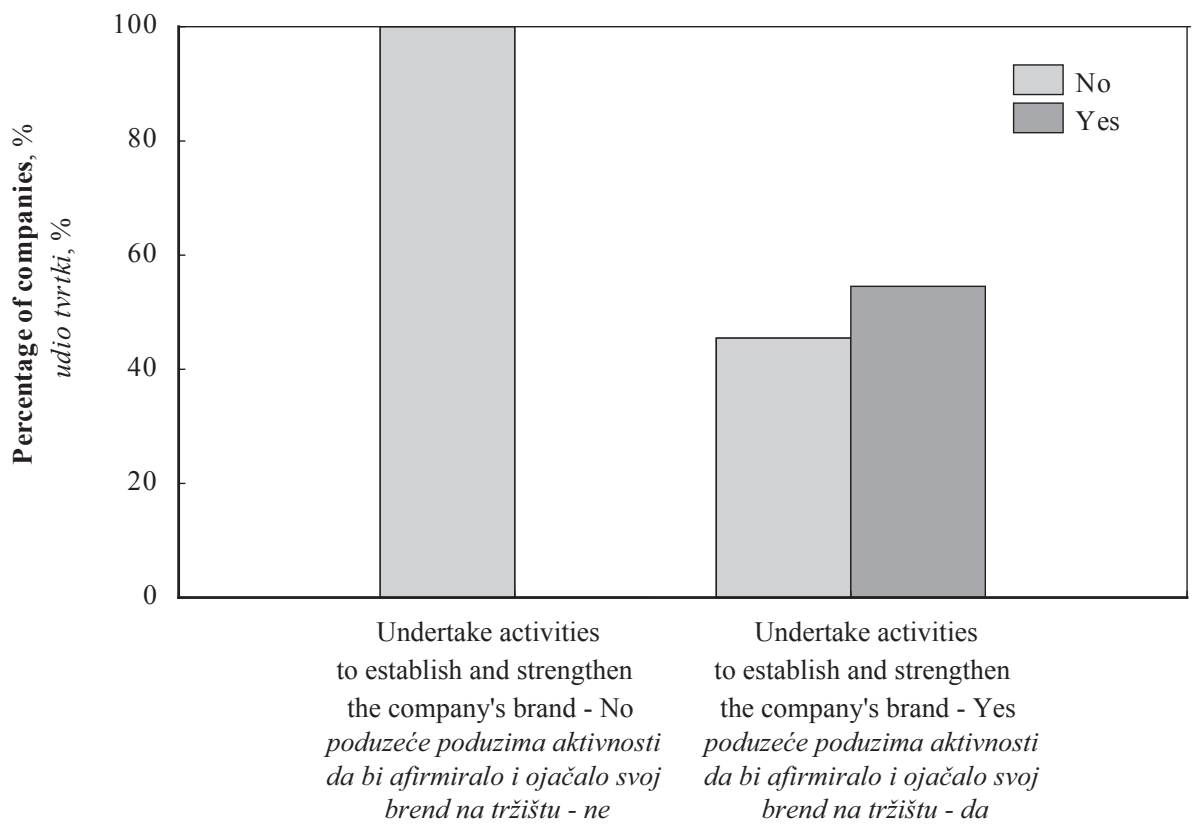

Figure 5 The distribution of analyzed enterprises in terms of their use of information on the length of the warranty period in their advertising materials depending on activities undertaken by the enterprise to establish and strengthen the position of its brand in the market

Slika 5. Raspodjela analiziranih poduzeća sa stajališta korištenja informacijama o duljini razdoblja jamstva za proizvode u reklamnim materijalima ovisno o aktivnostima koje poduzeća poduzimaju da bi afirmirali i ojačali svoj brand na tržištu

Do you use the information

on the length of the warranty period in your marketing materials? Koristite li se informacijama o duljini razdoblja jamstva u vašim marketinškim materijalima?

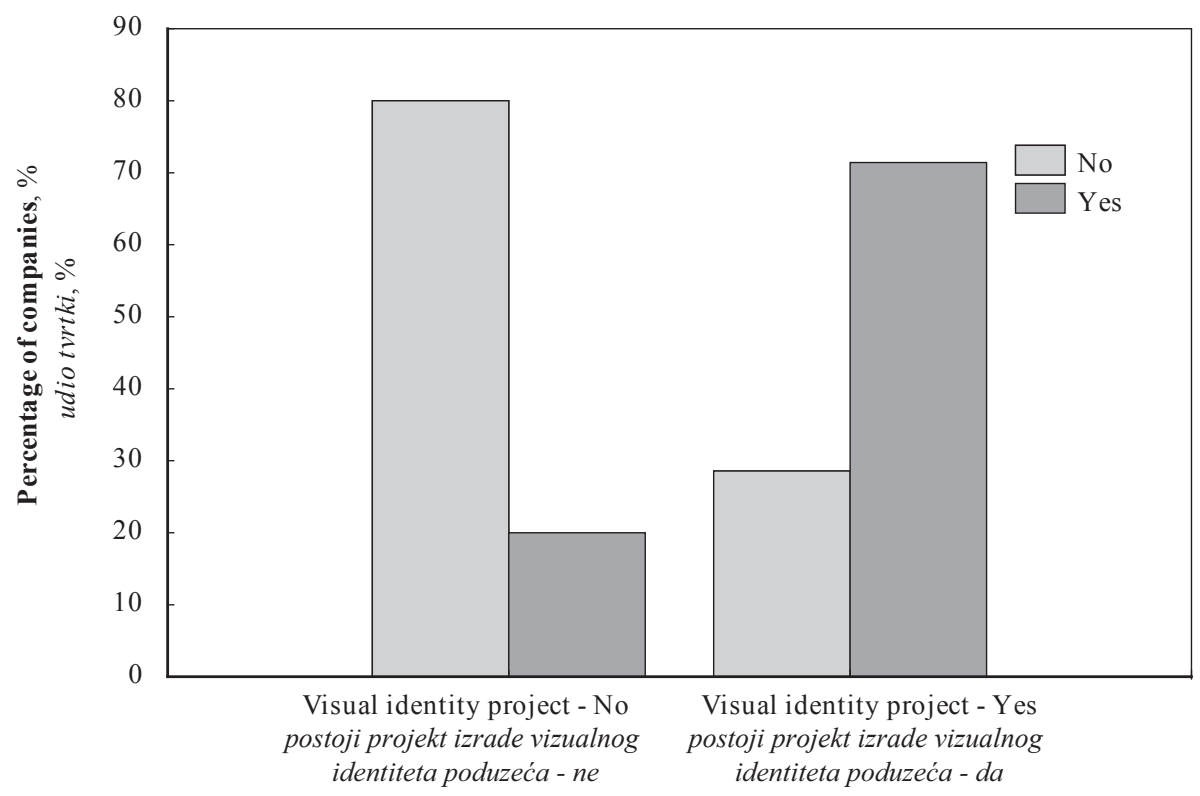

Figure 6 The distribution of analyzed enterprises in terms of the use of information on the length of the warranty period in their advertising materials depending on the existence of a visual identity project in the enterprise

Slika 6. Raspodjela analiziranih poduzeća sa stajališta uporabe informacija o duljini razdoblja jamstva za proizvode u reklamnim materijalima ovisno o postojanju projekta izrade vizualnog identiteta poduzeća 
Table 2 Results of the chi-square independence test for variables: the use of information on the length of the warranty period in their advertising materials and development of the brand based on the company visual identity project

Tablica 2. Rezultati $\chi^{2}$-testa za varijable korištenje informacijama o duljini razdoblja jamstva za proizvode u reklamnim materijalima i razvoj branda na temelju projekta izrade vizualnog identiteta poduzeća

\begin{tabular}{|l|c|c|c|}
\hline & $\chi^{2}$ & $\begin{array}{c}\text { Number of degrees of freedom } \\
\text { Stupanj slobode }\end{array}$ & $\begin{array}{c}\text { Level of significance } \\
\text { Razina signifikantnosti }\end{array}$ \\
\hline$\chi 2$ Pearson & 3.0857 & $D f=1$ & $p=0.079$ \\
\hline Contingency coefficient / Koeficijent kontingencije & 0.4523 & & \\
\hline$\tau$-b Kendall's coefficient / Kendallov koeficijent & 0.5071 & & \\
\hline
\end{tabular}

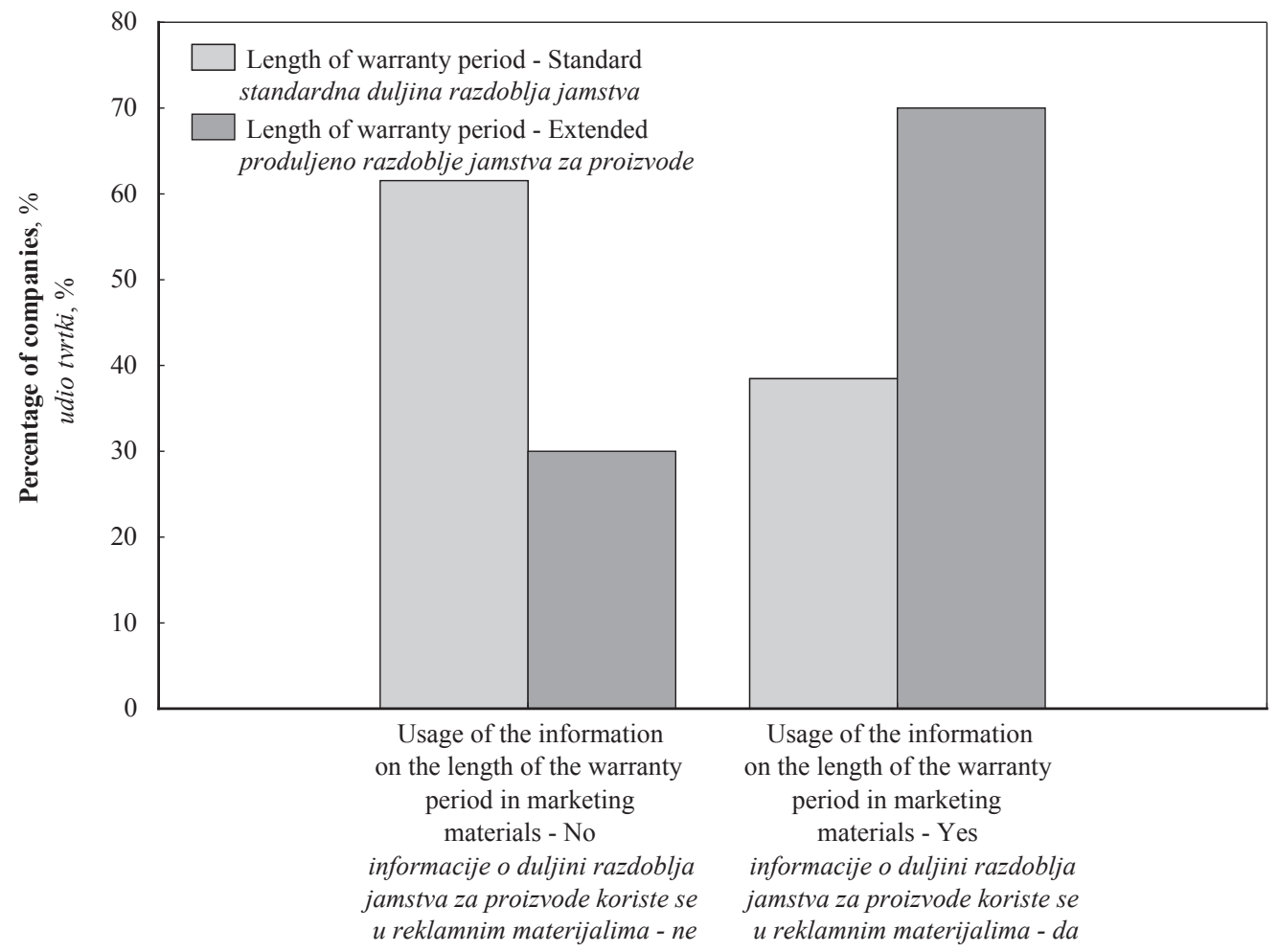

Figure 7 The distribution of analyzed enterprises in terms of the use of information on the length of the warranty period in their advertising materials depending on the offered length of warranty period

Slika 7. Raspodjela analiziranih poduzeća sa stajališta korištenja informacijama o duljini razdoblja jamstva za proizvode $u$ reklamnim materijalima ovisno o ponuđenom razdoblju jamstva za proizvod

tween the incorporation of information on the length of the warranty period for manufactured products in the advertising materials of the company and the realization of a strategy connected with the establishment of the brand based on the company visual identity project. The moderate strength of the dependence between analyzed variables is indicated by the value of the contingency coefficient $(C=0.4522670)$. The strength and the positive direction of the discussed dependence have also been evidenced by Kendall's $\tau$-b coefficient amounting to 0.5070925 , which indicates a positive correlation between the investigated variables (Tab. 2).

It should also be mentioned here that, among companies using information on the length of the warranty period in their marketing activity, as many as $70 \%$ offered an extended period of 3 up to 5 years (Figure 7).

In order to correctly define relationships between the discussed variables, the hierarchical classification of cluster analysis was applied, using Ward's method. This analysis included additionally the type of manufactured furniture. Results of cluster analysis show that, in the analyzed enterprises, two distinct main groups are found (Figure 8). The obtained results made it possible to accurately identify enterprises similar in terms of the dependence between the use of information concerning the length of the warranty period in advertising materials, the length of the offered warranty period and the type of manufactured furniture.

The first of the distinguished groups of enterprises is characterized by offering an extended warranty period for manufactured products, at the same time emphasizing in their advertising campaigns additional benefits consumers receive, connected with the extended length of the warranty period. This group includes most typically enterprises producing kitchen furniture as well as furniture for children and teenagers and nonupholstered furniture both for housing facilities and office interiors. The second group comprises companies offering a standard warranty period specified by the legal regulations. In contrast to the firms described above, these companies present this information in their marketing materials much less frequently. 


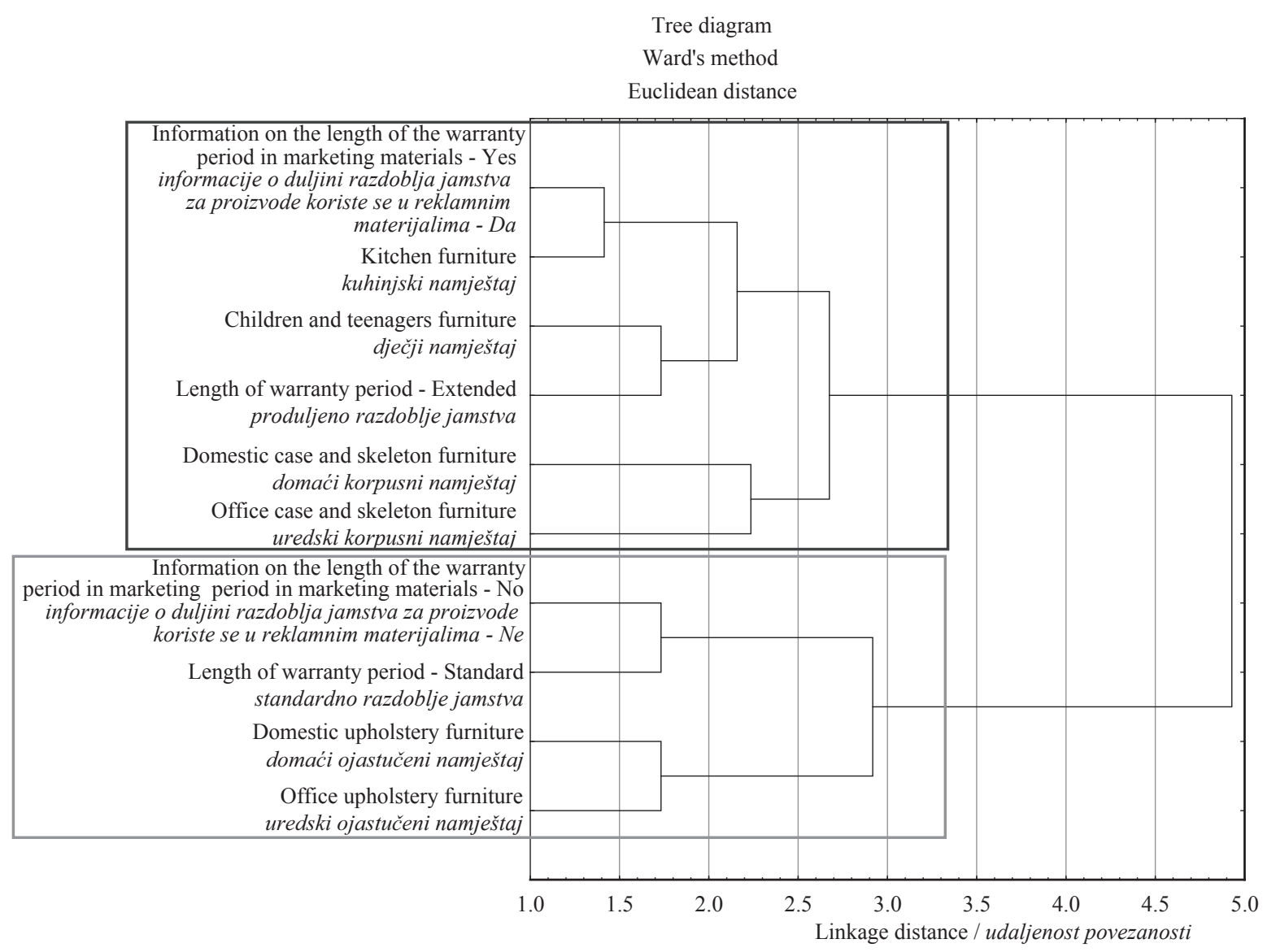

Figure 8 A graphic presentation of the results of cluster analysis for variables: incorporation of information concerning the length of the warranty period in advertising materials, the length of the offered warranty period and the type of manufactured furniture

Slika 8. Grafička prezentacija rezultata klasterske analize za ove varijable: korištenje informacijama o duljini razdoblja jamstva za proizvode u reklamnim materijalima i ponuđeno razdoblje jamstva za proizvod i vrstu namještaja

Tree diagram

Ward's method

Euclidean distance

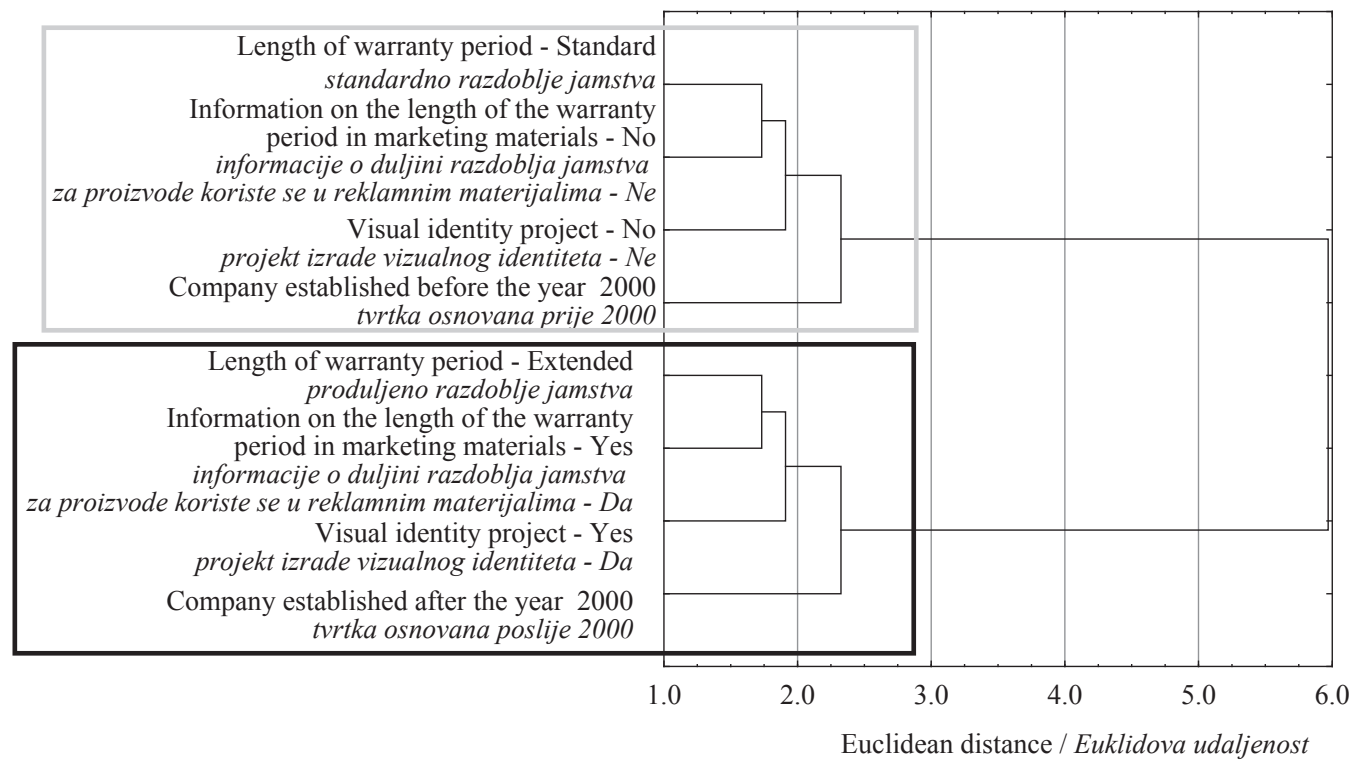

Figure 9 A graphic presentation of results of cluster analysis for variables: publishing information on the length of the warranty period in advertising materials, the length of the offered warranty period, having a visual identity project and the date when the company was established

Slika 9. Grafička prezentacija rezultata klasterske analize za ove varijable: objava informacija o duljini razdoblja jamstva za proizvode u reklamnim materijalima, ponuđeno razdoblje jamstva za proizvod, provedba projekta izrade vizualnog identiteta poduzeća i datum osnivanja poduzeća 
2D Plot of Column Coordinates

Input table (rows*columns): 6 × 6 (Burt's Table)

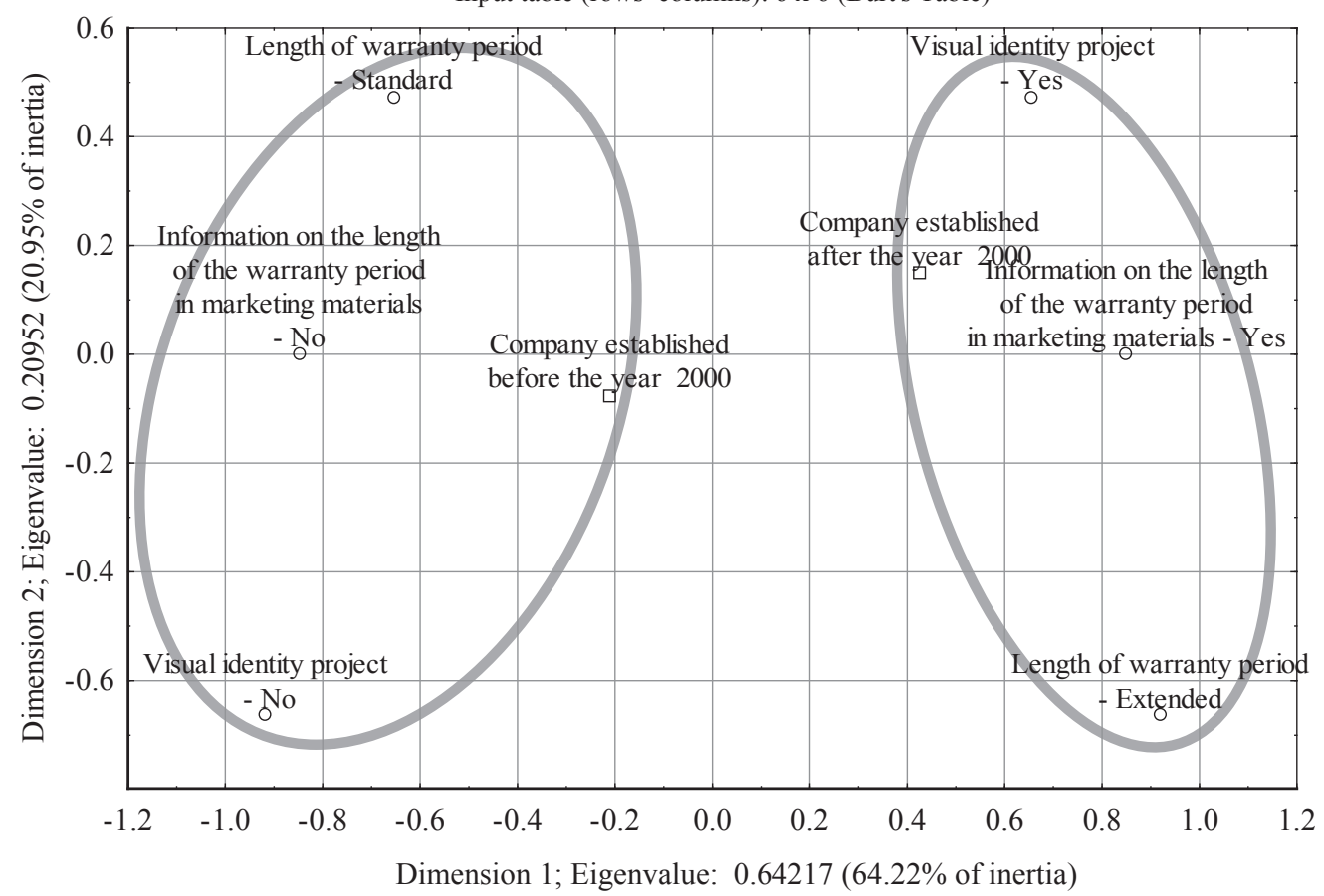

Figure 10 A graphic presentation of results of correspondence analysis for variables specifying the use of information concerning the length of the warranty period in advertising materials, the length of the offered warranty period, having a visual identity projects; additional points: the date when the company was established

Slika 10. Grafička prezentacija rezultata analize korespondencije za ove varijable: objavljene informacije o duljini razdoblja jamstva za proizvode u reklamnim materijalima, ponuđeno razdoblje jamstva za proizvod, provedba projekta izrade vizualnog identiteta poduzeća i za dodatnu varijablu - datum osnivanja poduzeća

The analysis was performed to identify the manner in which furniture enterprises establish their competitive edge and strengthen their positive image in the market based on quality, reliability and warranty for manufactured products. During this analysis, it was decided to focus additionally on whether the enterprise had a visual identity project and on the date the firm was founded. In order to verify the character of relationships between the above mentioned variants of analyzed variables, the hierarchical classification of cluster analysis was conducted using Ward's method (Figure 9). Results of cluster analysis suggest that two markedly distinct main groups may be distinguished in the investigated enterprises. One group comprises enterprises offering a standard warranty period, not mentioning that fact in their advertising campaigns. These companies frequently do not have a special visual identity project developed. Most firms in that group were established in the 1980s and 1990s. The other group is composed of enterprises using information on the length of the warranty period to fight competition in the market. At the same time, they offer a longer warranty period for manufactured products than that required by the legal regulations. They also have a visual identity project, thus realizing a long-term strategy of creation of their image in the market. This group comprises primarily enterprises established after the year 2000. This is confirmed by the results of investigations conducted by Innis and Unnava (1991), who suggest that the application of an extended warranty period and information of that fact in advertising materials may be particularly advantageous for new companies, still establishing their position in the market and striving to gain consumer loyalty and trust.

It was decided to apply a two-dimensional solution space. A graphic presentation of the results of correspondence analysis indicates differences between the 2 groups of enterprises (Figure 10). It confirmed the results of cluster analysis, as a result of which 2 groups of traits characterizing the investigated enterprises were identified, co-existing and connected with the use of information concerning the length of the warranty period in advertising materials, the length of the offered warranty period, having a visual identity project developed and the date when the company was founded. This confirms e.g. the results of a study by Innis and Unnava (1991), who showed that effectiveness of the use of a warranty as a tool in the creation of competitive edge is greater in the case of new brands, companies still striving to gain a stable position in the market.

\section{CONCLUSION}

\section{ZAKLJUČAK}

The results present the level of use of information concerning new product warranty in the marketing materials of furniture manufacturers operating in Poland and Slovenia. 
Based on the conducted investigations, the following conclusions were drawn:

1. It was shown that information on the length of the warranty period was primarily presented in advertising materials by manufacturers of furniture for children and kitchen furniture (all of the investigated enterprises manufacturing such furniture). This is connected e.g. with the fact that customers expected a very long period of use of kitchen furniture, and were concerned about the safety of use in the case of furniture for children and teenagers. Information on the length of the warranty period was given much less frequently (e.g. $22 \%$ ) in the advertising materials of companies manufacturing upholstered furniture for housing facilities.

2. Among companies using in their marketing activity the information on the length of the warranty period, as many as $70 \%$ offered an extended period covering 3 to 5 years. When offering an additional bonus in the form of extended warranty, they used it as a tool in the competitive fight in the market.

3. The study showed coexistence of variables connected with the offered warranty period, the use of information concerning warranty in advertising materials, implementation of a long-term strategy for design management and the development of a positive image of the company in the market based on the comprehensive visual identity project and the limited number of years since the company has been operating in the market.

4. No significant differences were shown between the selected Slovenian and Polish enterprises regarding the level of use of information concerning the length of warranty in their marketing activity. Both in the investigated Polish and Slovenian enterprises, it amounted to approx. $50 \%$.

\section{Acknowledgements - Zahvala}

The examined issues constitute a part of the project: StarDust of the Baltic Sea Region Programme 2007 - 2013: The Strategic Project in Trans-national Commercial Activities in Research \& Innovation, Clusters and in SME- Networks.

This work was partly financed by the European Union (European Regional Development Fund and European Neighbourhood and Partnership Instrument).

\section{REFERENCES}

\section{LITERATURA}

1. Chien, Y. H.; Sheu, S. H.; Chen, J. A., 2005: Determining optimal warranty periods from the seller's perspective and optimal out-of-warranty replacement age from the buyers perspective. International Journal of Systems Science, 36 (10): 631-637. http://dx.doi.org/10.1080/00207720500219054.

2. Gremyr, I.; Arvidsson, M.; Johansson, P., 2003: Robust design Methodology: status in the Swedish manufacturing industry. Quality and Reliability Engineering International, 19: 285-293. http://dx.doi.org/10.1002/qre.584.

3. Innis, D. E.; Unnava, H. R., 1991: The Usefulness of Products Warranties for Reputable and new Brands. Advances in Consumer Research, 18: 317-322.
4. Kłos, R.; Fabisiak, B., 2010: Reliability aspect of furniture design. The proceedings of the $21^{\text {st }}$ International Scientific Conference: Wood is good - transfer of knowledge in practice as a way out of the crisis AMBIENTA: 59-64.

5. Kłos, R.; Fabisiak, B., 2013a: Possibilities of reliability theory application in the process of furniture design. Wood Research, 58(1): 113-121.

6. Kłos, R.; Fabisiak, B., 2013b: Analysis of aspects of product warranty and reliability in selected furniture manufacturing companies. Annals of Warsaw University of Life Sciences - SGGW, Forestry and Wood Technology, 83: 42-46.

7. Knauf, M., 2015: Understanding the consumer: Multimodal market research on consumer attitudes in Germany towards lightweight furniture and lightweight materials in furniture design. European Journal of Wood and Wood Products, 73: 259-270. http://dx.doi.org/10.1007/s00107-014-0866-9.

8. Kotler, P., 2000: Marketing Management. New Jersey: Prentice-Hall.

9. Kotler, P.; Armstrong, M.; Saunders, J.; Wong, V., 2002: Marketing. Warszawa: PWE.

10. Kozak, R. A.; Maness, T. C., 2003: A system for continuous process improvement in wood products manufacturing. Holz als Roh- und Werkstoff, 6: 95-102. http://dx.doi.org/10.1007/s00107-003-0366-9.

11. Majeske, K. D.; Lynch-Carisb, T.; Herrinb, G., 1997: Evaluating product and process design changes with warranty data. International Journal of Production Economics, 50 (2-3): 79-89. http://dx.doi.org/10.1016/S09255273(97)00034-0.

12. Menezes, M. A. J.; Currim, I. S., 1992: An approach for determination of warranty length. International Journal of Research in Marketing, 9 (2): 177-195. http://dx.doi.org/10.1016/0167-8116(92)90037-L.

13. Murthy, D. N. P., 2006: Product warranty and reliability. Annals of Operations Research, 143: 133-146. http:// dx.doi.org/10.1007/s10479-006-7377-y.

14. Murthy, D. N. P., 2007: Product reliability and warranty: an overview and future research. Produção, 17 (3): 426434. http://dx.doi.org/10.1590/S0103-65132007000300003.

15. Murthy, D. N. P.; Djamaludin, I., 2002: New product warranty: A literature review. International Journal of Production Economics, 79 (3): 231-260.

16. Oblak, L.; Glavonjić, B., 2014: Model for the evaluation of radio advertisement for the sale of timber products. Drvna industrija, 65 (4): 303-308. http://dx.doi.org/10.5552/drind.2014.1357.

17. Ojurović, R.; Moro, M.; Šegotić, K.; Grladinović, T.; Oblak, L., 2013: Analysis of the investment in wood processing and furniture manufacturing entities by key factors of competitiveness. Drvna industrija, 64 (2): 131137. http://dx.doi.org/10.5552/drind.2013.1235.

18. Pakarinen, T. J.; Asikainen, A. T., 2001: Consumer segments for wooden household furniture. Holz als Rohund Werkstoff, 59: 217-227. http://dx.doi.org/10.1007/s001070100187.

19. Ratnasingam, J., 2003: A matter of design in the South East Asian wooden furniture industry. Holz als Roh- und Werkstoff, 6: 151-154. http://dx.doi.org/10.1007/s00107-003-0375-8.

20. Ratnasingam, J.; Perkins, M.; Reid, H., 1997: Fatigue: it's relevance to furniture. Holz als Roh- und Werkstoff, 55: 297-300. http://dx.doi.org/10.1007/s001070050232. 
..... Fabisiak, Kłos, Hrovatin: New Product Warranty: Empirical Evidence from Polish and...

21. Sander, P. C.; Brombacher, A. C., 2000: Analysis of quality information flows in the product creation process of high-volume consumer products. International Journal of Production Economics, 67 (1): 37-52. http://dx.doi.org/10.1016/S0925-5273(00)00008-6.

22. Schubert, R., 1979: Möbelnormung und Möbelprüfung. Holz als Roh- und Werkstoff, 37: 1-7. http://dx.doi.org/10.1007/BF02614991.

23. Sinclair, S. A.; Hansen, B. G., 1993: The relationship between purchase decisions and quality assessment of office furniture. Wood and Fiber Science, 25: 142-152.

24. Smardzewski, J., 2005: Niezawodność konstrukcji mebli skrzyniowych [Reliability of case type furniture constructions]. Przemysł Drzewny, 2: 24-27 (in Polish).

25. Smardzewski, J., 2009: The reliability of joints and cabinet furniture. Wood Research, 54 (1): 67-76.

26. Udell, J. G.; Anderson, E. E., 1968: The Product Warranty as an Element of Competitive Strategy. The Journal of Marketing, 32: 1-8. http://dx.doi.org/10.2307/1249330.

27. Vickery, S. K.; Dröge, C.; Markland, R., 1997: Dimensions of manufacturing strength in the furniture industry. Journal of Operations Management, 15: 317-330. http://dx.doi.org/10.1016/S0272-6963(97)00012-0.

28. Ward, J. H., 1963: Hierarchical Grouping to Optimize an Objective Function. Journal of the American statistical association, 58: 236-244.
29. Wiener, J. L., 1985: Are Warranties Accurate Signals of Product Reliability? Journal of Consumer Research, 12: 245-250.

30. Zhoua, Ch.; Chinnamb, R. B.; Korostelev, A., 2012: Hazard rate models for early detection of reliability problems using information from warranty databases and upstream supply chain. International Journal of Production Economics, 139 (1): 180-195.

http://dx.doi.org/10.1016/j.ijpe.2012.04.007.

\section{Corresponding address:}

Assoc. Prof. BEATA FABISIAK, Ph. D.

Department of Furniture Design

Faculty of Wood Technology

Poznan University of Life Sciences

Wojska Polskiego Street 38/42

60-637 Poznan, POLAND

e-mail: beata.fabisiak@up.poznan.pl 